\title{
Doing gender and age: The case of informal elderly care in the Czech Republic
}

\author{
By RADKA DUDOVÁ*
}

\begin{abstract}
This article seeks to describe and explain some of the factors behind the prevalence of women in informal care for seniors. It presents a qualitative study of women who are caring for a frail elderly parent in the Czech Republic. Care is seen as a space where gender and other intersecting identities are performed and this has specific subjective, structural and material consequences. The author draws on biographical interviews with women caregivers and shows how they "do gender and age" in their narratives of how and why they made the decision to provide care and how they actually provide care. The author identifies situations and circumstances in which gender categories and gender relations shift and are destabilised by changes in society. The Czech Republic is a country with a history of state socialism and with traditionally large numbers of women in the workforce, but it also has a highly traditional gender culture.
\end{abstract}

Keywords: age, elderly care, gender, informal care, women.

\section{Introduction}

Despite some differences that derive from disparate welfare-state regimes and policy mixes (Bettio \& Verashchagina 2012; Katz 2009; Naldini et al. 2016),

${ }^{*}$ Institute of Sociology of the Czech Academy of Sciences, Czech Republic 
International Journal of Ageing and Later Life

around the world (even in the most affluent countries) most elderly care is organised within the family (Guberman et al. 1992; Suitor et al. 2011). Elderly care is moreover deeply gendered, in terms of both who receives care and who provides it. Women - daughters, daughters-in-law, wives and sisters - continue to be the main providers of informal care for the elderly at home (Bracke et al. 2008). Recent data indicate that this is equally true in the Czech Republic (see Dudová 2015a; Klímová Chaloupková 2013; Přidalová 2007).

In this article, I try to shed light on some of the reasons why most (family) care for the elderly is provided by women, and to this end I draw on biographical narrative research that I conducted among women caring for an elderly parent in the Czech Republic. The Czech Republic is a post-socialist country, where the availability of formal care services is limited and trust in institutional care is low, but where there is also a long history of a relatively high level of women's participation in the labour market. Most elderly care is provided at home by (female) family members. Until they retire, working women have to juggle work and a job with their role as a caregiver. This article looks at women's narratives of how and why they decided to care for an elderly parent and at the actual care work they perform in order to analyse how women caregivers "do gender" in care. The aim is to show how elderly care is gendered and to explain some of the factors behind the prevalence of women in informal elderly care in the context of a country with a familialist welfare state, but where there is also a high rate of women's employment. What positions do women occupy in the discourses and practices of care? What social structures do they thus (re)produce, and how do these structures determine their available positions and choices? I set to show that instead of just doing "gender," women caregivers do "gendered age," which may have important consequences for the future of elderly care in the Czech Republic.

\section{Context}

According to data from the longitudinal SHARE study, the Czech Republic, along with Poland, has the largest share of elderly care that is provided informally, that is, outside an institution, in Europe: $97 \%$ of the occasional care needs and $78.5 \%$ of the daily care needs of elderly persons 
are attended to by family members or friends (Bettio \& Verashchagina 2012). Data from a representative study of the Czech population aged 25-60 years (Lifecourses 2010) conducted in $2010^{1}$ indicate that it is primarily women who provide informal care - both personal everyday and occasional care - for elderly family members. Women make up $80 \%$ of primary caregivers, that is, caregivers who attend to daily hygiene and feeding needs. According to the SHARE Wave 5 (2013) dataset, men also care for elderly family members, but they provide care with less frequency and the form of care is less intense, and their role in caregiving tends to decrease as a seniors' care needs grow (Dudová \&Vohlídalová 2018).

During the state-socialist era (especially in the 1960s and 1970s), Czechoslovakia introduced different kinds of residential care facilities for the elderly and a system of home-help care services. However, in the 1980s, residential care facilities only had the capacity to accommodate the needs of $15 \%$ of the population aged $80+$ and professional home-care services met the needs of another 20\% (Maříková \& Plasová 2012). After the political shift in 1989, the availability of residential care facilities decreased. Although since then the number of places in residential care facilities has been steadily increasing, the share of the demand for institutional care these facilities are able to meet has fallen further (to $10 \%$ of the $80+$ population), while the number of rejected applicants for residential care has soared. The first government measures aimed at supporting informal family care were introduced back in the 1970s, and as the economy was liberalised in the course of the 1990s and 2000s, the state gave priority to family-based elderly care. The opinion that formal care services should only be used if there are no informal providers, that is, family members, to provide care, or if they fail to do so, is now widely shared by policy-makers, experts and the public (Dudová 2015a). In 2006, the care allowance for caregivers that was introduced in 1976 was replaced by a new allowance that is much higher and is paid directly to care recipients so that they can buy care services or pay a family member to provide care. Only about one-third of the recipients of this care allowance use it

\footnotetext{
1 The Lifecourses 2010 dataset consists of data on 4000 respondents aged 25-60 years, forming a representative sample of the Czech population in terms of the standard quotas for survey-respondent characteristics (set for gender, age, size of the place of residence and region).
} 
International Journal of Ageing and Later Life

to pay for formal care services; the rest rely exclusively on care provided by family members (National Strategy 2016: 16). Currently, only one-fifth of elderly persons in need of everyday care live in residential (health or social) care or use formal (professional) care services provided at home (Nešporová et al. 2008). The rest receive informal care provided by family members; there is, however, no law that makes adult children legally responsible for attending to the care needs of their elderly parents.

The Czech eldercare system is a system in flux. The reform of the system in 2006 envisioned the formation of a quasi-market in elderly care. According to Sirovátka and Válková (2017), this reform was an exemplary market failure. While the declared objective was to widen the range of social services on offer and to encourage the development of domiciliary care instead of residential care, this did not happen, mainly because of the poor implementation and funding of the reform. This has since led to a decrease in the availability of public care services that have not been offset by the emergence of services in the private sector: $46 \%$ of the providers are public and $47 \%$ are non-profit organisations and churches, and about $7 \%$ of service providers are private and profit-oriented. The same public funding rules apply to all registered services regardless of what organisation or institution is providing them (National Strategy 2016: 33, data from 2012).

Unlike elderly care, childcare services (for children older than 3 years) have been able to provide almost universal coverage of childcare needs since the 1960s. This has made it easier for women to be a part of the labour force. Nonetheless, in the case of children up to the age of 3 years, coverage has decreased since the 1990s to the point where less than $3 \%$ of children aged 0-3 years are in childcare, while parental leave has been extended to 4 years. The long career breaks women must take to care for young children negatively impact their position on the labour market and reinforce the traditional division of labour in the family (see e.g. Saxonberg \& Sirovátka 2006). According to the typology of welfare states developed by Saraceno and Keck (2011: 373-374), the Czech Republic belongs to the type of countries that support familialism (offering care leaves and allowances to family caregivers) and where publicly funded long-term care services are not widely available or affordable.

The issue of care provision has become controversial internationally as women's employment rates have increased and they have become 
unwilling or unable to perform care and other household work the way they did in the past - without visibility, recognition or support from other actors in society (see Jacobs 2003). In the Czech society, the "refamilialisation" of elderly care has occurred in a situation where women's participation in the workforce is high - and has been high since the 1960s. The share of working women among all women of an economically active age rose sharply from 55\% in 1949 to $73 \%$ in 1959 and soared to more than $85 \%$ in the 1970 s and the 1980 s, majority of them working full-time (Křižková \& Vohlídalová 2009: 39, 47). At the same time, the retirement age for women remained comparatively low, ranging between 58 and 63 years of age for women born in 1956, depending on the number of children they had - a woman who had raised two children could retire at age 60 . However, the retirement age is gradually being raised and is higher with each cohort; a woman born in 1966 who has two children will retire at age 65 . Women may thus be facing contradictory expectations as they enter the "third age" (see Dudová 2015b; Laslett 1991): they have to keep working for as long as possible but are also expected to care personally for elderly relatives.

The Czech Republic is a post-socialist country in the Central-East European region, and within this region it is the country in which the post-1989 economic transformation and the accompanying process of refamilialisation has had the strongest impact on gender (see Hašková \& Dudová 2017). The Czech Republic can thus serve as a good example on which to demonstrate the different kinds of consequences that arise from the connection between feminity and elderly care (or from the construction of femininity in the practices and discourses of elderly care). In this context, where there is a high rate of women's employment, but also a very traditional gender culture, women piece together their life stories using contradictory repertoires.

\section{Theoretical Background}

There are a number of theories that seek to explain the prevalence of women in long-term care for seniors. These explanations refer to the role of early gender socialisation, structural factors (the socially determined gender division of labour, inequality in the labour market and in society in general), emotional bonds and close relationships (between a mother and daughter), 
International Journal of Ageing and Later Life

the preference for care from a child of the same sex (and mothers, as women, tend to live longer) or the different gendered normative expectations about the obligations of intergenerational solidarity. All these explanations are relevant. Yet, in the light of the empirical evidence on the great range of care practices that exist, they seem insufficient. This is because each one usually focuses on just a single dimension of the problem. They do not explain the fact that when there is a female in the family she is (automatically) the potential caregiver and the one who is most likely to "obviously" and "naturally" assume this role. Nor do they provide any insight into those situations where women in fact refuse to assume this role or have only limited involvement in the provision of care.

A more comprehensive explanation can be found in general theories of gender that integrate these dimensions. Joan W. Scott (1986) understands gender as a constitutive element of social relationships based on perceived differences between the sexes that involves four elements: culturally available symbols and myths; normative concepts that set forth interpretations of the meanings of these symbols and demand certain types of action in response to them (and define such actions as the only ones that are obvious and correct); social institutions and organisations (family and kinship, the labour market, education and the polity); and subjective identity (socialisation, the acceptance or construction of a masculine or feminine identity). These four elements are always interrelated; no one of them operates in isolation from the others. When asking how elderly care is gendered we need to pay attention to all of them.

However, all these elements are shaped, confirmed and altered through social interactions. Judith Butler proposes understanding gender as performative - as a series of repeated acts that create the effect of the stability and substantiality of gender. The gendered subject is then constituted by these acts. Gender is a mandatory performance that takes place in the context of a regulatory network of penalties, sanctions and taboos, all of which must be adhered to if a person is to be intelligible to others and to qualify as a subject, or as "real." The performance is neither conscious, nor voluntary nor external to the subject (Butler 1999: 25, 179, 190). Similarly, West and Zimmerman argue that gender should be viewed as something that is "accomplished" or that is continuously created and reconstructed through actions that conform to the expected behaviours of women and 
men (West and Zimmerman 1987: 126). Gender is thus dynamic, it is something that "we think" and "we do" (Gherardi 1994). As such, it acquires meaning through the social practices that constitute it (Bruni et al. 2005). Care is a performance space in which gender is enacted; it represents one of the many domains in which the "doing" of gender occurs. It involves not just the caregivers but also those who receive care - both parties "do" gender through their interactions with each other, with other people and with the external institutions that are tied up with informal care.

Language and how it is used are the main instruments by which social actors perform gender and enact gender norms (Speer 2005). According to discursive psychology, self and identity (including gender identity) must be seen as "being accomplished in the course of social interactions; reconstructed from moment to moment within specific discursive and rhetorical contexts, and distributed across social contexts" (Edley 2001: 205). Women, when speaking about their experiences of providing care, use "culturally familiar and habitual lines of argument comprised from recognisable themes, common places, and tropes" (Edley 2001: 202) that may denote the provision of care as feminine or link femininity with providing care, and they thereby position themselves as "women." Femininity must be conceptualised not as the cause or the reason why women take on the role of caregiver, but as a consequence of their assuming this role (Edley 2001: 192). In order to understand why care for the elderly is so associated with women and why women dominate in the caregiving role, it is necessary to examine how gender is "done" within a given culture, that is, what kind of self-representation and self-perception (in connection with caregiving) a particular culture endorses and promotes if a person is to be regarded as and feel like a "real woman" or a "real man," or what positions people can take in the discourses and practices of care in order to produce and reproduce or transform their gender identities.

Concurrently, we need to recognise how care is situated in the wider system of the division of labour in society and social institutions and within the family and the labour market in particular, which means understanding what activities and positions are considered appropriate and desirable for women and for men and how these activities are socially recognised and validated. The external structures and institutions that influence the actions of women caregivers and their interactions with others 
International Journal of Ageing and Later Life

while they provide care are seen as simultanously the causes and the consequences of the construction of gender. Although these structures are the product of human action, and are constantly being reproduced, reinforced and legitimised by these actions, once they are put in place they constrain people's actions and are perceived by people as external pressures or forces that they have no influence over (Bourdieu 2002). However, the existence of these structures is dependent on the perpetual repetition of them by subjects through their actions (Butler 1999). This opens the door to the transformation of categories and power relations, that is, for "undoing gender" (Risman 2009).

\section{Methodology}

In this study, I draw on a qualitative biographical study that focused on women caring for an elderly and dependent mother or, in some cases, caring for both parents. The study concentrated on middle-aged women (who, according to available data, are the people most likely to become caregivers; see Klímová Chaloupková 2013); my respondents were between the ages of 48 and 60 and the parents they cared for were aged 75 or over. Some of them were of pre-retirement age, while others were already retired. The research sample was selected to ensure that in one portion of cases (a total of 16), the elderly person who had received care was deceased, while in the other portion (13 cases) the women were still providing care at the time of the interview. In this way, it was possible to view the period of care as a life stage with a duration period and an end. The sample was created using the snowball method. First, respondents were recruited from among my acquaintances who then referred me to other people in their social networks. Special attention was paid to including women from diverse socio-economic backgrounds, education levels and family situations. The interviews were conducted in the capital of the Czech Republic (Prague), in mid-sized and small communities in its vicinity, and in two remote rural regions. The sample included several women who at some point had decided to cease providing care within the family and to transfer their mother or father to residential care. In the second phase, this sample was expanded to include a sample of eight men providing care. The interviews with the men are used in this paper where necessary to offer a contrast to the women's narratives 
(to show how femininity is linked to care and care to femininity). A full analysis of the men's narratives is, however, presented elsewhere (Dudová \& Vohlídalová 2018).

The analysis omits the narratives of the persons receiving care. Although gender is enacted in the interactions of both parties in the caring process, and the way care is received probably plays an important role in how the caregivers speak about and perform their caring role, I decided to focus on the discourses of caregivers only. The issue I am interested in is the production and reproduction of femininity in the narratives of caring women, as I believe that understanding how this occurs will help explain why women dominate in elderly care. In the interviews, the caregivers were given the opportunity to express their own position in the space of the discourse on care. They were given this opportunity in the specific situation of a face-to-face discussion with a researcher one generation younger than them (the author of this paper), who acknowledged at the beginning of the interview that she herself had the experience of helping her mother to care for her grandmother.

I used the biographical interviewing method (see Schutze 1980). The women were first allowed to freely narrate their life story, and in the second part of the interview they were presented with questions. The narrative interviews served as a space in which the respondents discursively constructed and created gender in front of or in cooperation with the interviewer. Over the course of their narratives, the interviewed women were essentially "redoing gender" - both in the way they presented their decisions, actions and thoughts to the interviewer, and in the way they reinterpreted the events in their lives and what they felt others expected of them. The narratives were the medium through which they constituted their identity, including its gendered aspects, and reflected the cultural norms and expectations placed on them. The interviewer served as the audience before whom the respondent displayed and affirmed her gender identity and also served the respondent as a kind of arbiter assessing how much the narrator's actions and responses met the accountability standards of her gender category (West \& Zimmerman 1987). The narratives were created in the interaction between the interviewer and the interviewee, and the interviewees responded to who the interviewer was. Some social categories were visible and more or less readily available to them - my/the interviewer's age, gender, race and class (the author being a white woman one generation younger than the 
International Journal of Ageing and Later Life

respondents and working in academia); others were deliberately made explicit in the introduction to the interview (I shared my personal experience caring for my grandmother). The interviewees had every reason to assume that the interviewer/I shared the same cultural stories about care and gender (see Miller \& Glassner 2004: 127-131). Simultaneously, in the interviews the interviewees were conscious of responding to an audience, that audience being who they imagined would ultimately read the results of the research (in most cases they imagined the audience would be policy-makers and the academic community). In both cases, the ways the narrators did gender depended on the interactional situation and the gender assumptions that entered it.

The next step involved combining a "narrative analysis" with an "analysis of narratives" (Polkinghorne 1995). First, I focused on the timing and course of each individual story by creating "story maps" for each narrative. All the key data and the timing of events in the respondent's life were recorded in a story map, along with the respondent's interpretations of the events, to which I added my analytical comments. I then used the method of coding and creating categories that is used in grounded theory methodology (Charmaz 2006). After the first reading and line-by-line topical coding, I compared the interviews and the parts of a narrative within each individual interview. I paid special attention to contradictions and incongruencies occuring across the narratives and in the narratives, namely, those that emerged as the interview unfolded. Gradually, I linked the analysis of individual narratives and the system of categories to create a single interpretive frame - an "analytical narrative" (Charmaz 2003). The deviant cases, if they appeared in the course of the analytical work, were thoroughly examined and discussed in order to revise, broaden or confirm the patterns emerging from data analysis. The original analysis was conducted in Czech (the original language of the interviews and the native language of the author). The quotes selected for this article were translated into English by the author. While translating, an effort was made to present the data as faithfully and accurately as possible. It is necessary to aknowledge that the translation of the talk-in-interaction is not without problems. Together with the transcription, the translation of the interviews should be seen as a process of "double rendering," in which a layer of interpretation is added to the original data (Nikander 2008: 229). Czech and English come from different language groups and 
have different structures, semantics and syntax. The accuracy and transparency of the data could be increased by including the original quotes. However, as the subject of this paper is not a detailed linguistically oriented conversation analysis, to include the original would make the text less clear and readable. The author will readily share the text of the quotes in the original Czech upon e-mail request.

The analysis involved searching for key passages where respondents explicitly or implicitly talk about gender or construct gender through their talk. I paid attention to their inter-subjective interactions and experiences, institutional barriers and sources, social values and strategies for coping with different situations in life. The transcripts of the interviews provided me with a rich collection of material with which to study how the women, in interaction with me, constituted themselves as gendered subjects in order to construct gender in such a way that it appears stable and solid; how they enacted and reproduced gendered norms concerning care and thus constructed their gendered identity. I was also able to make note of any breaches and inconsistencies where their construction of gender is revealed to be unstable and fragile.

At the same time, the interviews allowed me to study the social organisation and structures of elderly care. Bertaux (2003) asserts that narrated life stories obtained from sociological interviews are a unique tool with which to observe these structures. Once a sufficient number of them have been gathered to allow for a comparison of a particular context or issue, they begin to reveal the "lines of social forces," that is, the existing social structures that shape social and historical processes. When people tell their life stories they are describing "how they hit these invisible lines, how these lines prevented them from doing what they wanted to do or, on the contrary, provided them with unexpected resources" (Bertaux 2003: 40). Their actions then either reinforce these lines or try to undermine them, and this applies equally to doing gender (Risman 2009). In the narratives of the women caregivers I interviewed, I looked for the discursive elements (terms, metaphors and figures of speech) that they used to construct their feminine identities in relation to care, but I also sought to identify any discursive elements that weakened or undid gender when the women resisted the structures that they felt had been imposed on them.

First, I examine the ways how the interviewed women presented their caring roles, and I show that this narrative is part of a shared normative 
International Journal of Ageing and Later Life

"cultural story." Then I focus on how women narratively re-created their gendered identities in the interview situation when they were talking about care. In the last part of the text, I study the ways in which identity is tied to social structures, which are simultaneously the causes and the consequences of how women perform femininity in care. I conclude that instead of just doing "gender," women caregivers do "gendered age" in their practices and narratives of caregiving.

\section{Taking on the Caregiver Role: "The Obvious Thing to Do"}

In most cases, at the beginning of the interview, the respondents portrayed the decision to take on the role of primary carer and to care informally at home for a family member as having occurred "naturally." They were either unable or unwilling to explain exactly why they had made the decision to assume this role. At the start of the narratives in particular, many of them claimed that they had never reflected or deliberated much on their decision to care for their mother or father. It was clear to me that it would be forever, till she dies. That was perfectly clear to me,
but I didn't dwell on it at all.... I did whatever I had to do, and somehow I didn't give it
any further thought. (Diana, age 63, working retiree - teacher)

...The idea of her going somewhere else or something, that was never for a moment considered. She was simply going to be at home. (Tamara, age 62, retired, previously a factory worker)

Out of the 29 respondents, 11 in the first minutes of their narrative used the word "samozr"ejme" - which is best translated as "self-evident" to describe how it came about that they became the primary caregivers. A respondent named Jarmila said for her assuming the caregiving role was "normal." Lenka used the term "natural," and Tamara said that no other solution "came into consideration." Others described the course of events that led to them becoming the primary caregivers as occurring without any questions being raised or other options considered. There were two exceptions: Vera decided to care for her mother, who was suffering from cognitive impairment, because she "was already retired" and so she thought she "will give it a try" (Věra, age 63, working senior teaching assistant), but she felt uneasy because her mother considered 
it "self-evident" that Věra would provide care, while Věra expected more appreciation from her. Those daughters who did not consider it "natural" that they should be the ones to provide care nevertheless were confronted with this expectation from others, that is, the mother who needed care. Another exception was Ana (age 55, nurse assistant), who stated that she deliberated for one month whether she would offer 24-hour care to her mother. However, she only began to deliberate over her decision when the care her mother required started to be very time-intensive and she had to leave her job in order to continue caregiving.

Further along, however, the narratives revealed that taking on the role of primary caregiver was not an entirely automatic and obvious decision. Viewpoints and considerations slowly came out in the narratives that pointed to factors that had entered into their decisions and events that had challenged the obviousness of the decision. Presenting the decision to provide care as obvious, self-evident and natural is part of the dominant "cultural story." According to Miller and Glassner (2004), quoting Richardson (1990:24), participating in a culture includes also participating in the narratives of that culture. The interviewed women used familiar narrative constructs that were usually based on stereotypes and on their "stock of knowledge at hand" (Schutz 1962). According to this cultural story, caring for a dependent elderly parent is the duty of any adult child (daughter). The women were drawing on narratives that emerged out of the social worlds around them (from what they thought everybody thinks, from what was expected from them and from what I, as their interlocutor, probably knew and took for granted). Only later, when trust had been established (between the respondents and me/the interviewer), did the respondents feel they were able to depart from the cultural stories and speak about their own experiences and express their doubts.

Lucie initially presented the decision to care for her mother as the obvious choice: "The way I saw it, one day I would be caring for my mother." She then said, however, that when her mother's health deteriorated to the point where she required 24-hour care, she began to consider seeking institutional care for her mother. When her mother first began to require more care, Lucie was working in a factory and was not supposed to retire for another 13 months. The fact that she was not yet retired was for her a legitimate reason for her being unable to immediately begin caring for her mother. 
International Journal of Ageing and Later Life

\begin{abstract}
And then my mother fell, she broke her hip and actually spent 13 months in the hospital, in the chronic care ward, she was transferred there several times from the surgery ward because I was still going to work at the time and there was no one to care for her. (Lucie, age 60, retired, previously a factory worker)
\end{abstract}

Her mother ought rightly to have remained in the chronic care ward for a maximum of 90 days (this is the time limit beyond which a patient must be relocated from a hospital to a long-term care facility); Lucie nevertheless managed to make an informal arrangement with the hospital to allow her mother to remain there longer until Lucie retired. Lucie said that she was unable to imagine what she would have done if she had had even longer to work before retiring; she would likely "have had to place my mother somewhere until I was able to be at home." Later in the interview I learnt that even when she retired, Lucie initially considered placing her mother in institutional care. She ultimately made the decision to care for her at home herself when she found there was no space available in any residential social care facility:

After those 13 months, then it was up to us [Lucie and her husband] whether we would take her home or whether we'd have to place her somewhere. But there was no space, nothing immediately available at the time. So we took her home, but I was retired by then, so we looked after her at home. (Lucie, age 60, retired, previously a factory worker)

Most of the women at first described the decision to care personally for a family member as an obvious one, but later their narratives revealed this was not entirely the case. Talking about caregiving is also talking about gender: presenting their acceptance of the care obligation to the interviewer as an automatic and obvious decision can be seen as a discursive practice of doing gender. At the beginning of the interviews, face to face with an unknown middle-class female interviewer, the women opted for a normative cultural story, and drew on a general cultural repertoire (Cameron 2001: 174) that portrayed them as accepting of the norm that it is a daughter's duty to provide personal care, regardless of what doubts, plans, considerations or deliberations may have surrounded the actual decision. As the interviews unfolded, it became clear that the women considered what time and space they had in which to provide care, the option of placing the senior in an institution or the (un)acceptability of deciding not to take on the responsibility of care. Most of these factors were gendered. 
The case of informal elderly care in the Czech Republic

\section{Gender Identities and the Norms of Care}

To explain why the respondents initially presented their decision to take on the role of primary caregiver as obvious and automatic, we shall consider subjective identities together with gendered norms. How did the women construct their feminine identity? What self-presentation and self-perception did they see as culturally endorsed and preferred? What kind of normative expectations have they encountered and shared? According to Deborah Cameron (2001: 174), when people talk about their identity or some aspect of it, they draw from a defined "range of culturally intelligible" ways in which to do so; to do otherwise, that is, to perform and construct their identity outside this "range of possibilities" would render them unintelligible to others. So when talking about their understanding of care, in order to be "intelligible to others" and at the very least to the interviewer, the women likewise had to choose from a limited range of gendered normative repertoires.

Social norms stem from the culture of care that exists in a given context (Pfau-Effinger 2005). According to Naldini et al. (2016), the Czech society is one that places great importance on intergenerational solidarity and family care, and one where women are more likely to build a "moral career" as caregivers. These two levels on which gender operates - subjective identities and gendered norms - were very much intertwined in the narratives, as gender identities are formed through the acceptance and performance (or refusal) of gendered norms, and the norms are constantly reproduced by the actions (and interactions) of individuals.

Although gender appears in the quantitative data to be the strongest predictor of participation in family care, the women caregivers did not themselves mention gender as the main reason as to why they had become the primary caregivers. The connection between femininity and care was so deeply embedded in their identities that they did not feel the need to draw attention to it. For the respondents, face to face with a female interviewer, there was an assumed gender understanding underlying the interview situation. The women could assume that I was "from the same place," that I knew and took for granted the stereotypes and assumptions about femininity in care and thus there was no need to explain. Instead, they presented a list of other factors that had led them into care. The link between gendered norms, identities and care became obvious in how they 
International Journal of Ageing and Later Life

referred to what role their brothers played in providing care (or, in other cases, how they remained silent on this matter), in their notions about what the provision of intimate physical care involves and in how they described the care that they expected in the future from their children. The unquestioned connection between femininity and care was made especially evident by the way they spoke about their sons (or brothers) and daughters. They spoke in terms that alluded to generally shared social knowledge about what boys and girls are like and what they do: "They say that girls lean more to their parents than boys" (Veronika); "Because she's the daughter," (Kamila, explaining who will take care of her once she will need care and why); "You know guys, they don't know how to do it" (Petra, talking about getting help with caregiving from her brother).

Their future expectations of care were pinned almost exclusively on their daughters and they either never even considered their sons as future caregivers or explicitly excused them from having to provide care because of their gender. In this way, they reproduced the gendered norms of care in their education of the next generation:

I probably wouldn't even want to live to an age where someone had to care for me. Because it's different when it's a mother and a daughter. I'm a daughter. Now, I have sons, what can you expect from boys? There it'll be about how, say, your daughter-inlaw relates to you. (Věra, age 63, working senior - teaching assistant)

Some women thought that their son or sons would be able to care for them in old age. The reason they gave was that their sons possessed certain traits considered by them as feminine:

Well, [laughter] you know, he's a boy. From a boy [you'd expect] that he'd put you somewhere or something. Definitely not, he'd care, but that's because he's more a compassionate kind of person. If he's down to his last coin and there's a collection, he'll give it to [the collection]. (Jarmila, age 72, working senior - factory worker)

Sylva's narrative serves as a good example on which to further analyse how gender was constructed in the interview situation. At the time of the interview, Sylva had been caring for both of her parents for several years. Her parents lived in a family home across the street from her and Sylva went to their home every day to help them. It was only later on in her narrative that Sylva mentioned that her brother was living with her parents, 
but that he refused to participate in any substantial way in providing care. It was only when the interviewer asked her directly about other family members that she even mentioned her brother and his wife. The respondents' silence about their brothers (which was observed also in the case of Lucie, Tamara, Marie and Veronika) reveals what standards of accountability men are held to in the eyes of the respondents when it comes to providing care.

Sylva later reported that her brother was involved in caring for her mother, but she (unlike other interviewees) considered his contribution insufficient. Here, she deviated from the cultural story and challenged the popular stereotype of daughters as caregivers, only to embrace the story again in the next step when speaking about intimate care. She wanted her brother to be more involved in providing care, but she also claimed that she could not expect him, for instance, to change his mother's diaper. Sylva regarded intimate tasks as her work, and while she did not entirely exclude her brother from having a role to play in care, she excluded him as a man from having to provide intimate care:

But then I can't tell my brother to change my mother's diaper. I could, but I won't, that's nonsense. He can't even take our mother to the toilet and I don't even want that from him. (Sylva, age 57, employed - branch manager)

It emerged in her narrative, however, that she did expect this kind of care from her brother's wife. Ultimately, Sylva presented the limited involvement of her brother in caring for their mother as a shortcoming of her sister-in law. Sylva's narrative illustrates how gendered the provision of intimate care for an elderly person is. Care is one of the fields where gender intersects with embodiment. The greater the degree of explicit body work involved, the more the activity is gendered, regardless of whether we are referring to the constructions of masculinities or femininities (Morgan et al. 2005: 9). The dirty parts of care work in particular are viewed mainly as women's work, and the feelings of disgust this work tends to evoke are further tied up with our society's understanding of femininity and masculinity (Isaksen 2005: 123).

Intimate care was deemed by the respondents to be stressful for both the caregiver and the care recipient. The caregivers have to devote themselves very intensively to providing care and have to overcome their own 
International Journal of Ageing and Later Life

barriers of embarrassment or disgust. The care recipients may experience fear because of the extremely intimate nature of this care, and because they are being forced to recognise their dependence, loss of control and consequently the loss of their own identity.

\footnotetext{
My husband helped me to lift her up, but it was very difficult because she was still aware of everything and didn't want to accept her son-in-law touching her. And being there when I was washing her. (...). And I can tell you, not everyone has a stomach for this. So he would help me to lift her up or to turn her, but I did the rest myself. (Tamara, age 62 , retired, previously a factory worker)
}

In this light, the majority of the interviewed women felt it right to limit as much as possible the number of persons involved in providing this type of care, preferably to just one person - the primary caregiver. They also presented themselves as experienced and resilient enough to be able to cope without difficulty with this type of care, which they claimed is "not for everyone." This consequently meant that the primary caregiver became almost irreplaceable, especially once it became necessary to provide the most demanding type of care. This feeling of irreplaceability may explain the greater burden of care placed on women and the higher level of stress women experience in connection with care ( Calasanti 2003).

The way the respondents spoke about caregiving in the interview situation (their choice of vocabulary and specific means of expression) and the main narrative line served them as the means by which they constructed their gender identity. Talking about care means also talking about gender, or talking gender into being. Being a woman involves appropriating certain behaviours in conversation (or in an interview in this case) that members of their society have ascribed with a gendered meaning (they are understood as "feminine") and presenting themselves through these behaviours to others (see Cameron 2011). In the case of my interviewees, this involved presenting themselves as the "obvious" caregivers, and speaking about women as better suited to providing care than men. It also involved establishing a sense of intimacy and solidarity with me as the interviewer, which they did by sharing their emotions and describing at length the details of their everyday experiences. When speaking about intimate bodily care, they described in detail situations in which they had to overcome their reluctance to deal with the bodily manifestations of the care recipient. 
I bought that foam like they have in hospitals, so when it happened, she stayed leaning on the bed, and I sprinkled her [with it], now it was flowing down like this, so we had this paper pulp, so[and] I used that to wipe it up... (Lucie, age 60, retired, previously a factory worker)

But that kind of help with washing and such, that was hard. Before I got used to the fact that they were my parents who... . You wash them, you see their bodies so dilapidated, it's not a pleasant feeling. I think that was probably the hardest thing for me. Now I don't care, but it really was not pleasant at first. (Diana, age 63, working retiree - teacher)

Some explicitly welcomed the interview as an opportunity to share and clarify their contradictory feelings. In contrast, all the men who were interviewed in the later phase of the research spoke in more general terms, avoiding any detailed description of specific tasks associated with bodily care (they simply spoke about "hygiene" or the "physiological needs" of their parents that had to be taken care of).

The majority of the women also spoke in detail about the relationships between their family members, and they articulated their feelings and concerns, their sadness, and their fear of losing a close relative or of failing to deal with a difficult situation. In contrast, the men were mostly neutral, avoiding personal comments or descriptions of their feelings, and using impersonal pronouns. Thus, they (both the men and the women) fulfilled gendered expectations about the "right" way to cope with and experience emotions.

And that, I can't think about that, because I feel terribly sorry about it ${ }^{2}$. That, that's probably for me the worst thing that I go through. That concern that I have to do everything, from ... she doesn't even recognise anymore what slippers are, what a shirt is, what sweatpants are, so it's obvious then. That for me is the worst and sometimes I break out in tears and can't stop them and I say to myself: What are you blubbering about, don't be silly. And I can't stop it, I have to cry it all out of me. (Helga, age 62, retired, previously a factory worker)

That's what you say, you have to get through somehow, somehow manage it. Then the worst thing was that one has to be careful not to overstrain himself. Because I once

2 Some parts of the text are underlined by the author in order to emphasise the main points in the analysis - the terms describing emotions, the personal and impersonal pronouns and nouns. 
International Journal of Ageing and Later Life

experienced this burnout syndrome, I know there should be no overdoing things, because then a person just won't have the energy. (Jindrich, male, age 51, employed, middle management)

Men and women shaped their narratives according to the different accountability standards considered to apply to masculinity or femininity. The women in the sample were much more often intent on providing, what they called, the "best possible care," while the men were focused more on providing "adequate care" (see Dudová \& Vohlídalová 2018). Women chose a style of narrative that can be termed "apologetic." They used the space of the interview to evaluate themselves in their role as a daughter and care provider. In the course of the narrative they measured themselves against the (unspoken) norms of "proper" care, and they oftentimes tried to come to terms with how, by their own measure, they fell short of those standards. All the women who provided care for a longer period of time mentioned situations and circumstances in which they had lost patience with the person they were caring for and did not respond in the ideal manner, or when they had yielded to their exhaustion or made a decision that was not consistent with their image of themselves or with general expectations. In most cases, they expected the interviewer to reassure them that they were providing care in the "right" way, and in several cases they even directly asked for this reassurance.

As Miller and Glassner's approach to the interview analysis (2004) implies, the way people do gender depends on the interactional situation and especially on the gender assumptions that enter it. Face to face with a woman interviewer, women and men will do gender differently. The women interviewed assumed that I shared their positions and stereotypes about care and femininity and they invited me to participate actively in the process of co-constructing their self (Cameron 2011). They were asking for a reaction, and specifically for a valuation of their caregiving. By contrast, the men who were interviewed sought during the interview to (re)assert their masculinity, which could be perceived as being undermined by their involvement in care, and they did this by using narrative styles that are viewed in our culture as masculine.

Even (or especially) in situations when the practices of actual caregiving could be interpreted as "undoing gender" - for example, when the women refused to provide care at home and chose residential care for 
their relatives, or in the cases where it was men providing their mothers with intimate care, the space of the interview was used in order to re-do gender. Again, in the interviews, while the men interviewed reinterpreted the care they provided as a managerial, instrumental task, used general and expert language, and portrayed themselves as efficient and rational actors, the women in their narratives questioned whether they were good enough as caregivers and expressed a wide range of emotions. These differences do not reflect "real" or "natural" differences between men and women, but they are a means by which gender is performed. They should be seen as more or less conscious strategies employed by the speakers in order to appear adequate and socially desirable actors in the context of gender-structured and normative social rules (Mills 2003).

\section{The Social Structures of Care}

Gender, however, doesn't operate solely on the level of interaction; it can also be understood as both the cause and the consequence of the social structures and institutions that influence caregivers' decisions and constrain their actions. While these structures are experienced by people as external to them, they can be conceptualised as the social and material consequences of the gender performance and the norms, sanctions and taboos associated with it.

The interviewed women stressed two "external" factors in their explanations of why they were the ones who had become the primary caregivers: their availability and their belief that there was no alternative. Their availability was determined by whether they were employed or were able to adjust their working hours to accommodate the need to provide care, and also by how free they were from, or were able to free themselves from, other care obligations. The story of Jana shows how being employed influences the decision to assume care and what consequences this decision may have.

Jana lived her entire life with her parents in their family home. She began caring for her ill mother shortly after the death of her father, who until then had provided some of the care for her mother. Jana was working in a low-level administrative job. Given that her wages were the household's primary income, she initially did not consider leaving work. Jana had a sister who took it for granted that Jana would assume responsibility 
International Journal of Ageing and Later Life

for caring for their parents since Jana had been living with her parents all her life and would inherit their home.

Her mother's health gradually deteriorated, and Jana tried to arrange care so that she could also continue working:

\footnotetext{
... Since I had my job too, I asked a neighbour and gave him the keys so that while I was away he could always go in and check things. It happened several times that she fell, and since her mobility was poor, one time she had a gash on her forehead and she was bleeding, she tripped over the heater. ... And then I also asked a woman from my street, and she used to come by and look after her when I wasn't there. (Jana, age 67, retired, previously an office clerk)
}

In the end she decided to take early retirement in order to care for her mother, but she had only been retired for three months when her mother's health deteriorated further. Jana was no longer able to cope with caring for her mother given her own health and her mother's weight. So she decided to place her in a long-term care institution.

For Jana, early retirement meant a loss of income from employment and a reduced pension, and, from her perspective, it was all ultimately for nothing. While at the time of the interview she regretted not having left work earlier, when it would still have been possible for her to care for her mother at home, it became apparent from her story that she could not financially afford to lose the income she had from her job or the reduction in her pension that retiring early entailed. Still, she interpreted the fact that she did not care for her mother herself as a failure, as her having failed as a daughter.

Eight of the women in the sample were already retired when the need to care for an elderly parent arose. They spoke of having reached retirement age as a key factor that had made the decision to assume the task of care much easier. And this was true even though half of them continued to work after retirement in part-time or temporary jobs. They claimed that these were jobs that they could easily leave or combine with care because the jobs tended to have more flexible or shorter working hours. Jana was the only one in the sample who had decided to retire before reaching the official retirement age in order to provide care. The official retirement age of the cohort of women in the research sample ranged between 55 and 61 years. For the other women, having reached retirement age was interpreted as the key precondition for making the decision to assume 
responsibility for care; the need to work, by contrast, was regarded as legitimate justification to seek some other form of care, for instance, in the formal sector.

This contrasts with the experience of the men who identified themselves as primary caregivers. The men did not see their jobs as something that interfered with their care obligations; they all worked full-time and had no intention of stopping work in the near future. The women caregivers did not want to leave their jobs to provide care as well, but they felt the need to justify this decision to themselves and to explain this decision during the interview. They envisioned providing care in a post-retirement timeline and imagined that they would gradually then spend more of their time on care. The men interviewed never mentioned the possibility of leaving or taking a break from their jobs, nor did they consider retirement as a precondition for providing (more) care. They planned to make use of formal or home-care services to meet any increase in how much time the care recipient in their lives required care.

The interviews did not bring any clear-cut evidence of the effects of social class on how the women spoke about or practised elderly care and combined it with paid work. The research sample comprises women of all socio-economic and educational categories, including low-skilled factory workers, managers and university teachers. Their motivations sometimes differed. Lower-income women of pre-retirement age said that they needed the money and therefore looked for other ways to organise care without having to leave the labour market. Women with higher income were usually motivated to continue working by the nature of their job. Still, the factors that led to them becoming the primary caregivers or using formal services were similar. An analysis of ISSP $2012^{3}$ data (Klímová Chaloupková 2013) similarly indicated that education, used as a proxy of socio-economic status, had no impact on the decision to provide informal care in the Czech Republic. This can be explained by the lack of both public formal care services in the country (which influences how much less educated and lower-income women participate

3 The International Social Survey Programme (ISSP) - 2012 Module Family and Changing Gender Roles IV. In the Czech Republic, the sample consisted of 1804 respondents aged $18+$, representative for the Czech population. 
International Journal of Ageing and Later Life

in informal caregiving) and private care services (which influence how much higher-educated and higher-income women end up taking on care responsibilities).

Jana's story further suggests that in the eyes of the respondents, fulltime informal care was only possible if other members of the family were able at least indirectly help in the provision of care. When the female respondents received assistance, in most cases it was from their spouse. This assistance did not mean that the duties and tasks of care were actually shared between them. Oftentimes it was simply a matter of the spouse being present at home while the respondent was at work, or it was that the spouse was able to provide financial support. The importance of this spousal assistance and support became most apparent in the narratives of the women who did not have a spouse - who were either single, divorced or widowed. All the non-married women saw their jobs as essential for them because they had no spousal income to rely on or anyone to share their expenses with. Consequently, they felt it impossible to take on full-time care on their own. According to ISSP 2012 data (Klímová Chaloupková 2013), Czech women living with a partner are $70 \%$ more likely to be providing informal care than women without a partner.

The last external factor mentioned by the respondents when they were explaining as to why they became caregivers was whether or not any alternatives to informal care were available. The narratives illustrate how a daughter's decision to care for her mother at home was often also a consequence of having no satisfactory alternative solution in the form of formal care. As Lucie's story made it clear, the decision to provide care at home in many cases was preceded by a period spent searching for suitable care services or institutions, although the decision itself was presented at the start of the interview as an obvious and automatic choice that was based solely on the belief that it is the responsibility and duty of a daughter to care for her mother. If the possibility to use quality professional care had existed, many of the respondents would likely have decided otherwise.

Tamara - who at the beginning of the interview stated twice, "There was no question at all of putting her somewhere else. She was simply staying at home" - herself undermined the obviousness of her decision to provide care 20 minutes into the interview: 


\begin{abstract}
...I took it on not out of the feeling that I owe it to them, but with the feeling that I simply have to do it. As I'd obtained information about various care institutions and all that. And I don't know, some people feel [formal care] is good enough, but I wasn't satisfied with it. (Tamara, age 62, retired, previously a factory worker)
\end{abstract}

It can be assumed that if formal care services deemed of adequate quality by the respondents had been available and affordable, they would have been less likely to become primary caregivers themselves. According to Kotsadam (2011), the quality and diversity of the formal care services that are available have a positive effect on their use, and their quality and availability also influence the "ethics of care" in a given country (in the sense of culturally shared care values and practices; see Flores et al. 2009). This in turn may have an effect on the gender division of work in the household, as has been suggested in a study on childcare by Ellingsaeter and Gulbrandsen (2007).

The lack of any alternative, that is, the unavailability of quality and accessible formal care, the earlier age at which women retire and the traditional division of labour in the family are thus the factors that lead women more than men to take on the role of primary care for an ageing parent, despite the high level of labour market participation among the working-age population of women. Conversely, being in pre-retirement age and having no life partner to rely on for financial and practical support constituted sufficient and legitimate reasons for women not to personally provide care for their parents. Structural factors - the lack of formal services of care, the early retirement age of women and their understanding of retirement as a time when they will be providing informal care and the acceptance of dependence on a partner's income - must however be considered to be not only a cause but also a consequence of the way women perform femininity in care.

\title{
Conclusion: Elderly Care and Doing Gender (and Age)
}

Based on biographical interviews with Czech women caring for an elderly parent, I have described and analysed the ways in which women narratively presented their "decision" to assume the responsibility of providing care to an elderly parent. When reinterpreting this life experience and presenting it in a face-to-face interview with a researcher, the respondents described this decision as an obvious and natural choice. They situated their narratives in a "cultural story" told from the point of view of the normative order, which offered them a general gendered cultural repertoire 
International Journal of Ageing and Later Life

from which to draw. Only later, as the interviews unfolded and trust was established, did they depart from the narrative in which it is taken for granted that daughters provide care, and did they begin to modify their accounts. In a deeper perspective, it is clear that at the given time there were many alternative ways more or less available to them in which care could have been provided or in which the stories could have been told. The result, however, was that it was a daughter or a daughter-in-law who assumed the responsibility of care (at least for some period of time).

Gender is constantly shaped and confirmed through interactions with other people. Women "did gender" when they performed care activities and in the interactions associated with these activities, and in this way they were constantly re-constructing their femininity in conformity with the prevailing norms and expectations. An example is their acceptance of responsibility for the provision of care and the automatic excusal of brothers from any such responsibility. The provision of intimate care formed a separate chapter altogether: The women considered it inappropriate for a man to provide this form of care, in conformity with heterosexual taboos, and at the same time they placed the needs of their parents (consistent care from one person) before their own (the need for rest or to share care with another person).

The case of the Czech Republic, as a post-socialist country, provides an example of a country in which the economic transformation and refamilialisation processes under way since 1989 have had a big impact on gendered social structures. Consequently, it provides a good illustration of the consequences of connecting feminity and elderly care in circumstances where the provision of care has been de-institutionalised and the norm of public responsibility for providing elderly care has been eroded and where we have seen the emergence of "welfare markets." The Czech Republic has a long history of there being large numbers of women in the workforce, but it also has a very traditional gender culture, little governmental support for informal and formal care, and a shortage of institutions providing formal care. Moreover, the official retirement age of women is low compared to other European countries and is currently still lower than the official retirement age for men. In their decision to provide care, women caregivers were influenced by existing institutions and structural arrangements: Given that they retired at a younger age, they 
were more available to provide care. The lack of good-quality services offering formal care led them to take on the responsibilities themselves. Given the conservative division of labour in the family, the women coped with care needs on their own and did not expect any help in providing hands-on care from their partner or brothers. By accepting the effects of these institutions and structures, they reproduced social institutions and structures through their own actions. For example, they regarded retirement age as the moment at which they should assume the role of primary caregiver, even though in many cases they continued to have jobs. If there had been no need for them to provide care, many of them would have continued to work in the job that they had before retiring. Because of the care duties that they perceived as their own, however, they often chose flexible working hours and more precarious job conditions with lower wages.

The respondents "re-did gender" during the interviews in the way they reconstructed their story: at first they described care as a responsibility that they "obviously" and "automatically" took on, positioning themselves as "women" in the normative cultural narrative, even though their stories gradually revealed a number of turning points that call into question how obvious this decision was. They presented themselves as irreplaceable in the caregiving role and as the only ones in the family capable of providing care. They expressed regret if they felt that they had not lived up to the norm, that they had been unable to provide care long enough or that they had not done everything they felt they could have for their parents' well-being. The different standards of accountability that women and men are held to were manifested in the different styles or discourses they used in the course of their narratives.

The use of different discursive styles was however also a result of the interactional situation of the interview - the interviewees responded to the visible categories of the interviewer, and gender was one of the most evident categories. The stories would have been told differently to a different interviewer, but this does not mean that the narratives do not give access to the social realities "out there." As Miller and Glassner put it, they "come out of worlds that exist outside of the interview itself" (2004: 131). The narrative constructs that the interviewed women shared and presented to the interviewer provide insight into the stock of knowledge 
International Journal of Ageing and Later Life

and cultural understandings that the women drew on to make sense of their experiences to themselves and to others, and to "create and maintain meaningful worlds" (Dawson \& Prus 1993: 166, in Miller \& Glassner 2004: 129), including their gender identities.

The narratives illustrate how the different levels on which gender manifests itself and is done are intertwined. Subjective gendered identities are linked to the overall family and care culture that exists in a given country: if there is a strong bias towards intergenerational obligations and informal care and a traditional gender division of labour, women are more likely to accept the obligation to care as part of their identities. Culture is intertwined with policies and institutions and each one influences the other (see Naldini et al. 2016: 627; Pfau-Effinger 2004). When formal care services are not available or not affordable, women are left with very limited choices. Explicit familialist policies (such as paying family members cash to provide care) then push them even more into providing the care themselves, as doing so gives them an alternative source of income.

Nevertheless, there were points in the narratives where the women could be seen to be "undoing gender," mainly when they presented "legitimate" reasons for not having to provide time-intensive care, such as not having reached the retirement age yet and still having paid work, not having a partner and being in need of one's own income or being able to obtain good-quality professional care services for the person in need of care. The most notable of the latter grounds for not providing care was the need to continue working until they reached retirement age. The women considered it evident that until they reached retirement age they would have to find some other way of getting care for their parents if they needed all-day care, usually by turning to formal institutional care, or by getting help from other family members. The relatively low official retirement age for women currently has the effect of reinforcing the connection between women and informal care in the Czech Republic. We could argue that instead of "doing gender," the women interviewed were "doing gendered age" (see Utrata 2011). The women accepted the assumptions about age, paid work and family status that oblige them to provide care for their elderly relatives once they reach the statutory retirement age, while the men did not face any such expectations. Informal elderly care thus serves as an example of age and gender intersectionality, by making visible how 
gendered identities, norms concerning age and gender, and social structures hold women accountable for providing intergenerational support.

In the case of the Czech Republic, we observe how women do and undo gender at the intersection of contradictory expectations: a traditional gender division of labour and a familialist care regime/culture that strengthens the link between femininity and care on one side, and the high full-time labour force participation of women on the other. With the raising of the statutory retirement age and the prolonging of working lives, doing "gendered age" (providing full-time informal care after retirement) may lead to a decrease in the availability of women to provide care.

\section{Acknowledgements}

This article is the outcome of research conducted with the support of the Czech Science Foundation (Grantová agentura České republiky), grant number 15-07898S.

\section{Corresponding author}

Radka Dudová, Institute of Sociology of the Czech Academy of Sciences, Jilská 1, 11000 Prague 1, Czech Republic. Email: radka.dudova@soc.cas.cz.

\section{References}

Bertaux, D. (2003). The usefulness of life stories for a realist and meaningful sociology. In R. Humphrey, R. Miller, \& E. Zdravomyslova (eds.), Biographical Research in Eastern Europe. Altered lives and broken biographies (pp. 39-52). Hampshire: Ashgate.

Bettio, F. \& Verashchagina, A. (2012). Long Term Care for the Elderly. Provisions and Providers in 33 Countries. Luxembourg: Publications Office of the European Union. Available on http://ec.europa.eu/justice/gender-equality/files/elderly_care_en.pdf (Accessed: May 18, 2015)

Bourdieu, P. (2002). Outline of a Theory of Practice. Cambridge: Cambridge University Press.

Bracke, P., Christiaens, W. \& Wauterickx, N. (2008). The pivotal role of women in informal care. Journal of Family Issues 29(10): 1348-1378. 
International Journal of Ageing and Later Life

Bruni, A., Gherardi, S. \& Poggio, B. (2005). Gender and Entrepreneurship: An Ethnographic Approach. New York: Routledge.

Butler, J. (1999). Gender Trouble. Feminism and the Subversion of Identity (1st ed. 1990). London: Routledge.

Calasanti, T. (2003). Masculinities and care work in old age. In S. Arber, K. Davidson \& J. Ginn (eds.), Gender and Ageing (pp. 15-30). Maidenhead, Philadelphia: Open University Press.

Cameron, D. (2011). Working With Spoken Discourse. London: Sage Publications.

Charmaz, K. (2003). Qualitative inteviewing and grounded theory analysis. In J. A. Holstein (ed.), Inside Interviewing (pp. 311-330). London: Sage.

Charmaz, K. (2006). Constructing Grounded Theory. A Practical Guide through Qualitative Analysis. Thousand Oaks, CA: Sage.

Dawson, L. L. \& Prus, R. C. (1993). Interactionist ethnography and postmodernist discourse: Affinities and disjunctures in approaching human lived experience. Studies in Symbolic Interaction Book Series 15: 147-77.

Dudová, R. (2015a). Postarat se ve stáří. Rodina a zajištění péče o seniory. Prague: Sociologické nakladatelství.

Dudová, R. (2015b). Caring for elderly parents: A new commitment of the third age. Czech Sociological Review 51(6): 903-927.

Dudová, R. \& Vohlídalová, M. (2018). Muži a ženy pečující o seniory v rodině. Sociologický časopis / Czech Sociological Review 54(2): 2019-251.

Edley, N. (2001). Analysing masculinity: Interpretative repertoires, ideological dilemmas and subject positions. In M. Wetherell, S. Taylor \& S. J. Yates (eds), Discourse and Data. A Guide for Analysis (pp. 189-228). London: Sage/Open University.

Ellingsaeter, A. L. \& Gulbrandsen, L. (2007). Closing the childcare gap: The interaction of childcare provision and mothers' agency in Norway. Journal of Social Policy 36(04): 649-669.

Flores, Y. G., Hinton, L., Barker, J. C., Franz, C. E. \& Velasquez, A. (2009). Beyond familism: A case study of the ethics of care of a Latina caregiver of an elderly parent with dementia. Health Care for Women International 30(12): 1055-1072.

Gherardi, S. (1994). The gender we think, the gender we do in our everyday organizational lives. Human Relations 47(6): 591-610. 
Guberman, N., Maheu, P. \& Maillé, C. (1992). Women as family caregivers: Why do they care? The Gerontologist 32(5): 607-617.

Hašková, H. \& Dudová, R. (2017). Precarious work and care responsibilities in the economic crisis. European Journal of Industrial Relations 23(1): 47-63.

Isaksen, L. W. (2005). Gender and care: The role of cultural ideas of dirt and disgust. In D. Morgan, B. Brandth \& E. Kvande (eds.), Gender, Bodies and Work (pp. 115-126). Aldershot: Ashgate.

Jacobs, T. (2003). Paying for informal care: A contradiction in terminis? European Societies 5(4): 397-417.

Katz, R. (2009). Intergenerational family relations and subjective wellbeing in old age: A cross-national study. European Journal of Ageing 6(2): 79-90.

Klímová Chaloupková, J. (2013). Neformální péče v rodině: sociodemografické charakteristiky pečujících osob [Informal family care: Sociodemografic characteristics of caring persons]. Data a výzkum - SDA Info 7(2): 107-123.

Kotsadam, A. (2011). Does informal eldercare impede women's employment? The case of European welfare states. Feminist Economics 17(2): 121-144.

Kř́žková, A. \& Vohlídalová, M. (2009). The labour market and work-life balance in the Czech Republic in historical perspective. In H. Hašková \& Z. Uhde (eds.), Women and Social Citizenship in Czech Society: Continuity and Change (pp. 35-78). Prague: Institute of Sociology.

Laslett, P. (1991). Fresh Map of Life: The Emergence of the Third Age. Cambridge: Harvard UP.

Lifecourses dataset 2010 (2013) [online]. Ver. 1.0. Institute of Sociology, Czech Academy of Sciences. Prague: Czech Social Science Data Archive, 2013 (Accessed March 20, 2014). doi: 10.14473/CSDA00047

Maříková, H. \& Plasová, B. (2012). Kontinuita anebo změna v systému zajištění péče o seniory v České republice od roku 1948 vzhledem k genderovanosti politik péče. [Continuity or change of the system of elderly care in the Czech Republic regarding the gendering of care policies]. Fórum Sociální Politiky 6(3): 2-7.

Miller, J. \& Glassner, B. (2004). The 'inside' and the 'outside'. Finding realities in interviews. In D. Silverman (ed.), Qualitative Research Theory, Method and Practice, (2nd ed., pp. 125-139). London: Sage Publications. 
International Journal of Ageing and Later Life

Mills, S. (2003). Third wave feminist linguistics and the analysis of sexism. Discourse Analysis Online. Available on https:/ / extra.shu.ac.uk/ daol/articles/open/2003/001/mills2003001.html (Accessed July 12, 2017)

Morgan, D., Brandth, B. \& Kvande, E. (2005). Thinking about gender, bodies and work. In D. Morgan, B. Brandth \& E. Kvande (eds.), Gender, Bodies and Work (pp. 1-15). Aldershot: Ashgate.

Naldini, M., Pavolini, E. \& Solera, C. (2016). Female employment and elderly care: The role of care policies and culture in 21 European countries. Work, Employment \& Society 30(4): 607-630.

National Strategy of the Development of Social Services for the Period of 2015-2025 /Národní strategie rozvoje sociálních služeb na období 2015-2025, 2016, Ministry of Labour and Social Affairs, Prague. Available on http://www.mpsv.cz/files/clanky/29714/NSRSS.pdf (Accessed October 15, 2016)

Nešporová, O., Svobodová, K. \& Vidovičová, L. (2008). Zajištění potřeb seniorůs di̊razem na roli nestátního sektoru [Ensuring the needs of senior citizens with the accent on the role of non-state sector]. Prague: VUPSV.

Nikander, P. (2008). Working with transcripts and translated data. Qualitative Research in Psychology 5(3): 225-231.

Pfau-Effinger, B. (2004). Development of Culture, Welfare States and Women's Employment in Europe. Aldershot: Ashgate.

Pfau-Effinger, B. (2005). Welfare state policies and the development of care arrangements. European Societies 7(2): 321-347.

Polkinghorne, D. E. (1995). Narrative configuration in qualitative analysis. International Journal of Qualitative Studies in Education 8(1): 5-23.

Přidalová, M. (2007). Pečujicí dcery a pečujicí synové (Rozhodnutí, se kterým můžu žit) [Caring daughters and caring sons (A decision I can live with)]. (Vol. 07/04). Brno: Institut pro výzkum reprodukce a integrace společnosti.

Richardson, L. (1990). Writing Strategies: Reaching Diverse Audiences. Newbury Park, CA: Sage.

Risman, B. J. (2009). From doing to undoing: Gender as we know it. Gender $\mathcal{E}$ Society 23(1): 81-84.

Saraceno, C. \& Keck, W. (2011). Towards an integrated approach for the analysis of gender equity in policies supporting paid work and care responsibilities. Demographic Research 25 (11): 371-406. 
Saxonberg, S. \& Sirovátka, T. (2006). Failing family policy in post-communist Central Europe. Journal of Comparative Policy Analysis: Research and Practice 8(2): 185-202.

Schutz, A. (1962). Collected Papers. Vol. 2. The Hague: Nijhoff.

Schutze, F. (1980). Prozesstrukturen des Lebensablaufs. In J. Matthes, A. Pfeifenberger \& M. Stosberg (eds.), Biographie in handlungswissenschaftlicher Perspektive (pp. 67-156). Nurnberg: Nurnberger Forschungsvereinigung.

Scott, J. W. (1986). Gender: A useful category of historical analysis. The American Historical Review 91(5): 1053-1075.

Sirovátka, T. \& Válková, J. (2017). Understanding Care Policies in Changing Times: Experiences and Lessons from the Czech Republic and Norway. Brno: MuniPress.

Speer, S. A. (2005). Gender Talk: Feminism, Discourse and Conversation Analysis. London: Routledge.

Suitor, J. J., Sechrist, J., Gilligan, M. \& Pillemer, K. (2011). Intergenerational relations in later-life families. In J. L. Angel (ed.), Handbook of Sociology of Aging (pp. 161-178). New York: Springer.

Utrata, J. (2011). Youth privilege: Doing age and gender in Russia's single-mother families. Gender \& Society 25(5): 616-641.

West, C. \& Zimmerman, D. H. (1987). Doing gender. Gender \& Society 1(2): 125-151. 
